\section{SOI: $\frac{1.1 / \text { TAS } \text { DOI: } 10.15863 /}{\text { International Scientific Journal }}$ Theoretical \& Applied Science}

p-ISSN: 2308-4944 (print) ｅ-ISSN: 2409-0085 (online)

Year: $2015 \quad$ Issue: $05 \quad$ Volume: 25

Published: $30.05 .2015 \quad$ http://T-Science.org

SECTION 11. Biology. Ecology. Veterinary.

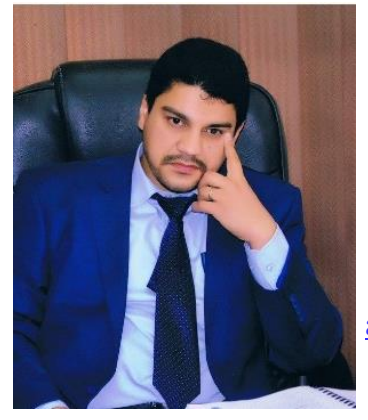

Ali Abid Abojassim
Assistant Professor,
doctor in Nuclear Physics and
Environmental,
Faculty of Science,
Department of Physics,
University of Kufa, Iraq
ali.alhameedawi@uokufa.edu.iq

Haider Salih Jaffat

Assistant Professor, doctor in Animal physiology Faculty of Science, Department of Biology,

University of Kufa, Iraq

Haider_salih1968@yahoo.com

Adhraa Baqir Hassan

Lecturer, doctor in Animal physiology Faculty of Science, Department of Biology,

University of Kufa, Iraq

abh_mscph@yahoo.com

\title{
EFFECTS OF GAMMA RADIATION ON SOME HEMATOLOGICAL PARAMETERS IN FEMALE RATS
}

\begin{abstract}
The effect of low exposure doses of gamma ray at doses of $0.055 \mathrm{~Gy}, 0.11$ Gy and 0.165 Gy on the some hematological parameters of albino female rats were investigated. At the end of exposure periods and Blood samples were collected for analyses. The results obtained when increases of gamma ray doses of rats caused significant, $p \leq 0.05$, decrease in the RBCs, $\mathrm{Hb}$ and $\mathrm{Ht} \%$. Also it was found elevation in MCV and MCH with increased exposure dose as well as significant decreases, $p \leq 0.05$, Platelets in decreasing with increasing of doses rate and while $\mathrm{MCHC} \%$ did not change significantly. But it was found when increases of gamma ray doses of rats caused significant, $p \leq 0.05$, decrease in WBCs count, lymphocytes count, monocytic, neutrophils, esinophiles and basophiles respective controls. These findings on the some hematological parameters suggest that the changes in blood parameters of the treated rats were due to the exposure of low doses of gamma ray.

Key words: cesium-137, physiological criteria, gamma irradiation, and female rats.

Language: English

Citation: Abojassim AA, Jaffat HS, Hassan AB (2015) EFFECTS OF GAMMA RADIATION ON SOME HEMATOLOGICAL PARAMETERS IN FEMALE RATS. ISJ Theoretical \& Applied Science 05 (25): 101-109. Soi: http://s-o-i.org/1.1/TAS*05(25)19 Doi: crossef http://dx.doi.org/10.15863/TAS.2015.05.25.19
\end{abstract}

\section{Introduction:}

Ionizing radiation affects people by depositing energy in body tissue, which can cause changes in the chemical balance of cell [1]. The energy associated with ionizing radiation is significantly greater than the bond energies of many molecules and can cause homolytic bond scission and the generation of secondary electrons. The time scale of the initial steps of energy deposition and molecular bond scission is on the order of $10^{-13} \mathrm{~s}$ [2]. The effect degree of the ionizing radiations depends on the type of radiation, energy of radiation, intensity of radiation and exposure time. The Radiation is thus seen to produce a biological effect by two mechanisms, directly by dissociating molecules following their excitation and ionization; and indirectly by the production of free radicals and hydrogen peroxide in the water of the body fluids [3]. The Gamma ray has no charge, and it has very high ionizing energy. Because of their high energy, gamma photons travel at the speed of light and can cover hundreds to thousands of meters in air before spending their energy. They can pass through many kinds of materials, including human tissue [4]. Physiological criteria such as the ability to degrade different substrates, casine, and xanthine were used for genus determination. Streptomyces are obligate aerobes, chemoorganotrops that need only an organic carbon source (such as glucose, starch, and glycerol), an inorganic nitrogen source, and a few mineral salts for grow. However, faster growth can be obtained in complex media containing, for instance, yeast extract, or other organic nitrogen sources. Trace elements contained in tap water are generally sufficient, but addition of iron manganese, zinc and 
ions can be beneficial [5]. The destructive effects and mutations from radiation were originally thought to be due primarily to direct content of high-energy rays and particles with vital centers of microbial cells. Highly free radicals resulting from water hydrolysis are most important factors contributing to lethal and sublethal changes in microbial cells [6]. There are some scientists modernly study effects of irradiation on different parts of rats. Allehyanim et al.[7] studied the effects of gamma rays in the dose rate range 0$5.6 \mathrm{~Gy}$ on RBCs membrane solubilization, of rats erythrocytes using sodium dodecyl sulfate (SDS). Omar Mohamed et al. [8] studied the effects of gamma rays in the dose rate $8 \mathrm{~Gy}$ on Whole Body of rats Induced Early Alterations in Biliary Secretion. Asrar M. Hawas[9] studied the effect of low dose (0.055 Gy) gamma-rays on certain essential metals namely $\mathrm{Fe}, \mathrm{Cu}, \mathrm{Zn}$ and $\mathrm{Ca}$ levels in various tissues (liver, kidney, testis, spleen, intestine, heart and brain) in rats. Also, lipid peroxidation as malondialdehyde (MDA) and metallothionein (MT) levels were measured in liver, kidney and testis. The aim of this study was estimated the effects of gamma rays in the low dose rate range 0-.012 Gy on Physiological Criteria in Female Rats.

\section{Materials and Methods}

\subsection{Experimental Animals and Irradiation}

12 rats were divided into 4 groups with 3 rats (R1) First group as control group did not receive any radiation, (R2) was irradiated with 0.055Gy, (R3) was irradiated with $0.11 \mathrm{~Gy}$ and (R4) was irradiated with $0.165 \mathrm{~Gy}$. Animals were housed under standardized conditions for light and temperature. A commercially prepared diet and clean drinking water were provided ad libitum. Irradiation was performed through the use of Cesium-137 source with $5 \mu \mathrm{Ci}$ from the International Atomic Energy Agency in a close system. The Cesium-137 radiation was taken in place was used so that three animals could be simultaneously irradiated.

\subsection{Blood sample collection method}

At the end of exposure periods, each group of animals was anaesthetizes with ether, and then blood samples were collected by heart puncture on heparin containing tubes. One part of blood was taken for whole blood viscosity measurement.

\subsection{Determination of Hematological Parameters}

The red blood cells (RBC) and white blood cells (WBC) counts were determined by the improved Neubauer haemocytometer method. The haemoglobin $(\mathrm{Hb})$ concentration was determined according to [10], using the cyanomethaemoglobin method. The packed cell volume (PCV) was determined by the micro-haematocrit method according to [11]. Schilling method of differential lecukocyte count was used to determine the distribution of the various white blood cells [12]. Mean corpuscular volume (MCV), mean corpuscular haemoglobin $(\mathrm{MCH})$ and mean corpuscular haemoglobin concentration (MCHC) were computed according to [12].

\subsection{Statistical evaluation.}

Statistical analysis for evaluation of the results was done by calculating arithmetic mean and standard deviation for red blood cells and hemoglobin measurements. All these measurements had been done for all groups. Results were expressed as mean \pm standard deviation for each group. The results were evaluated by Student's unpaired t-tests.

\section{Results and discussions}

Figures (1-7) show the effect of gamma irradiation on the Hematological parameters in female rats. There are significant decreases $(\mathrm{P} \leq 0.05)$ in $\mathrm{RBCs}, \mathrm{Hb}$ and $\mathrm{Ht} \%$ in groups exposed to 0.055 Gy, 0.11 Gy and 0.165 Gy gamma irradiation when compared to the control $(4.9,13.7$ and -40$)$ for low respectively. $\mathrm{MCV}$ and $\mathrm{MCH}$ increased significantly $(\mathrm{P} \leq 0.05)$ with irradiation doses compared to the control group, while $\mathrm{MCHC} \%$ did not change significantly in most treated groups. Platelets count decreased significantly $(\mathrm{P} \leq 0.05)$ in the group exposed to irradiation dose $(0.165 \mathrm{~Gy})$. 


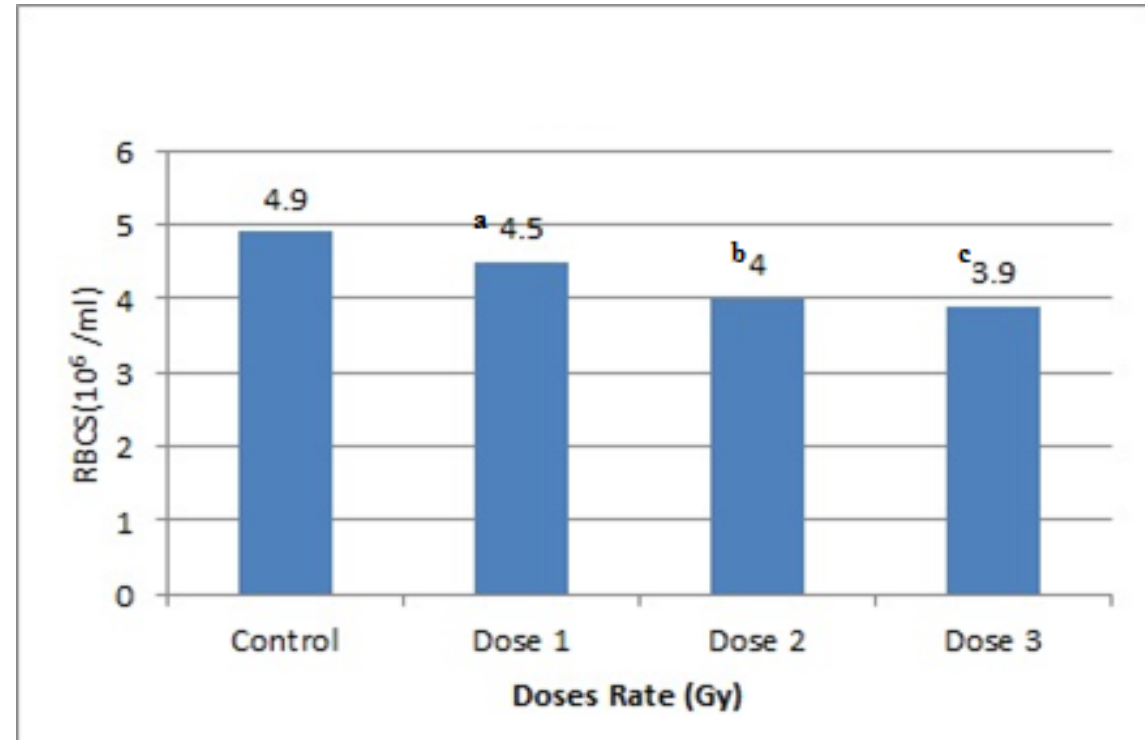

Figure 1 - Effect of low doses of gamma ray on RBCS counts in female rats (a, $\mathrm{d}$ and c: means significant difference at $\mathbf{P}<0.05$ )

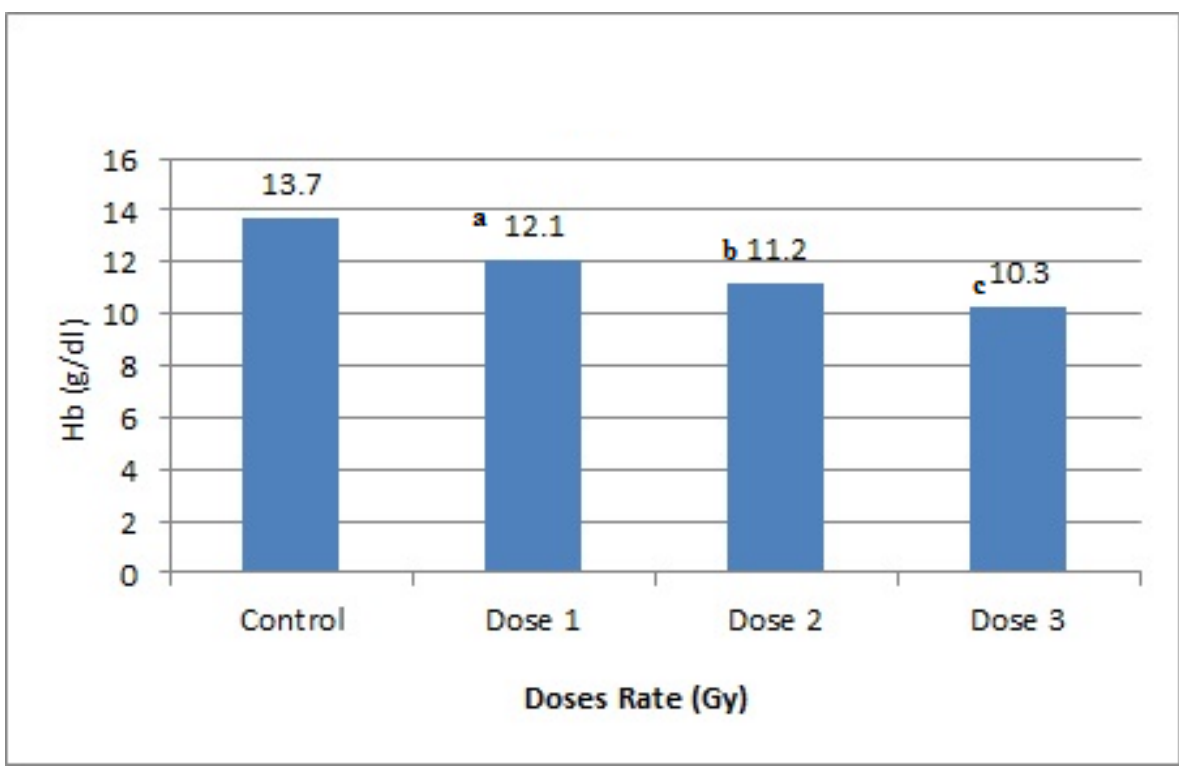

Figure 2 - Effect of low doses of gamma ray on $\mathrm{Hb}(\mathrm{g} / \mathrm{dl})$ counts in female rats . (a, b and c: means significant difference at $\mathbf{P}<0.05$ ) 
Impact Factor ISRA (India) $\quad=\mathbf{1 . 3 4 4}$

Impact Factor ISI (Dubai, UAE) $=\mathbf{0 . 8 2 9}$

based on International Citation Report (ICR)

Impact Factor GIF (Australia) $\quad \mathbf{0} \mathbf{0 . 3 5 6}$
Impact Factor JIF

$=1.500$

Impact Factor SIS (USA)

$=0.912$

Impact Factor РИНЦ (Russia) $=0.179$

Impact Factor ESJI (KZ)

$=1.042$

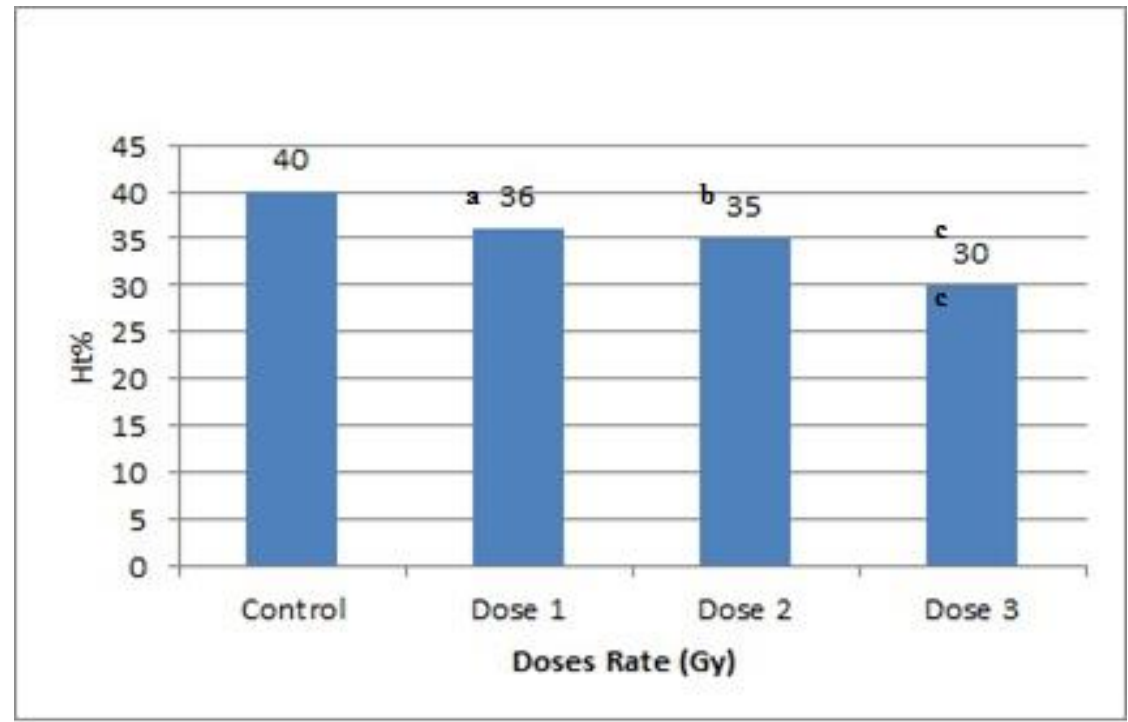

Figure 3 - Effect of low doses of gamma ray on $\mathrm{Ht} \%$ counts in female rats .

(a, $d$ and c: means significant difference at $P<0.05$ )

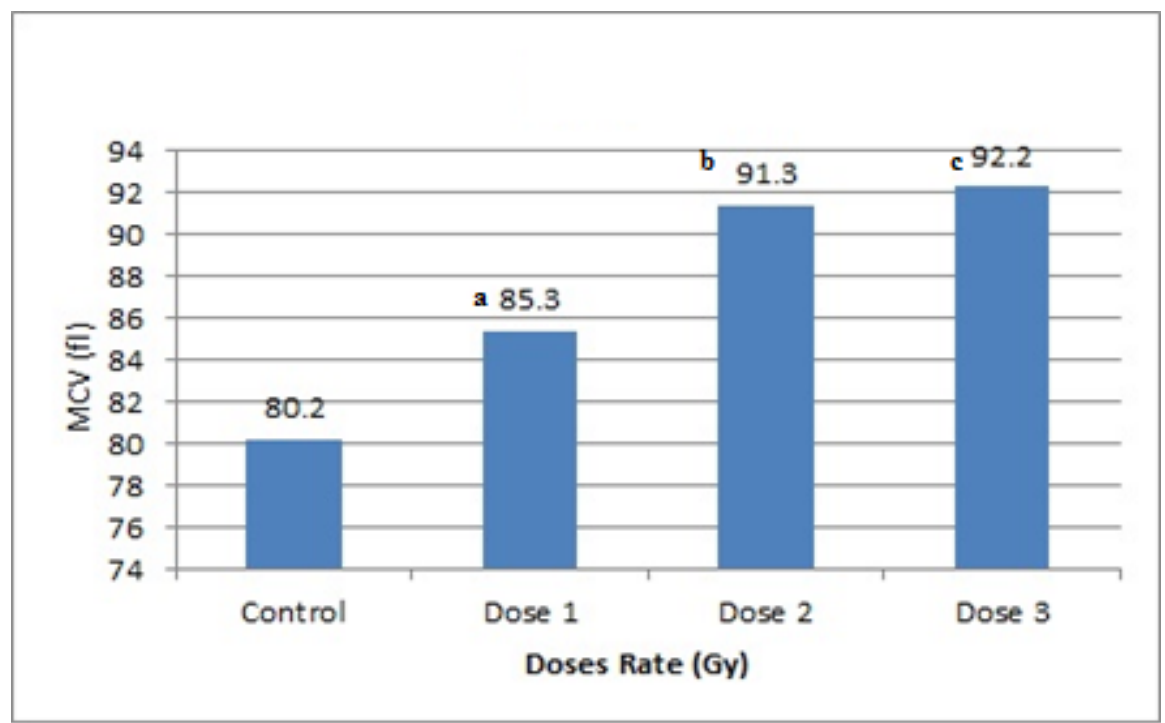

Figure 4 - Effect of low doses of gamma ray on $\mathrm{MCV}(\mathrm{fl})$ counts in female rats (a, $b$ and $c$ :means significant difference at $P<0.05$ ) 


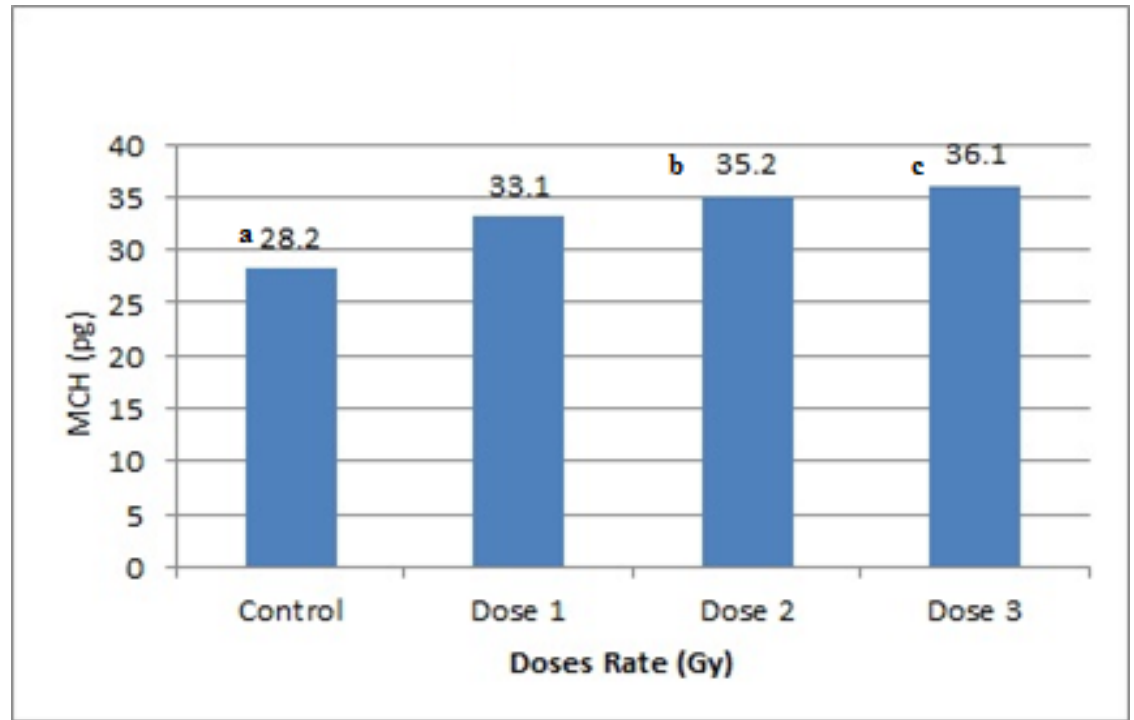

Figure 5 - Effect of low doses of gamma ray on $\mathrm{MCH}(\mathrm{Pgl})$ counts in female rats . (a, $b$ and c:means significant difference at $\mathbf{P}<0.05$ )

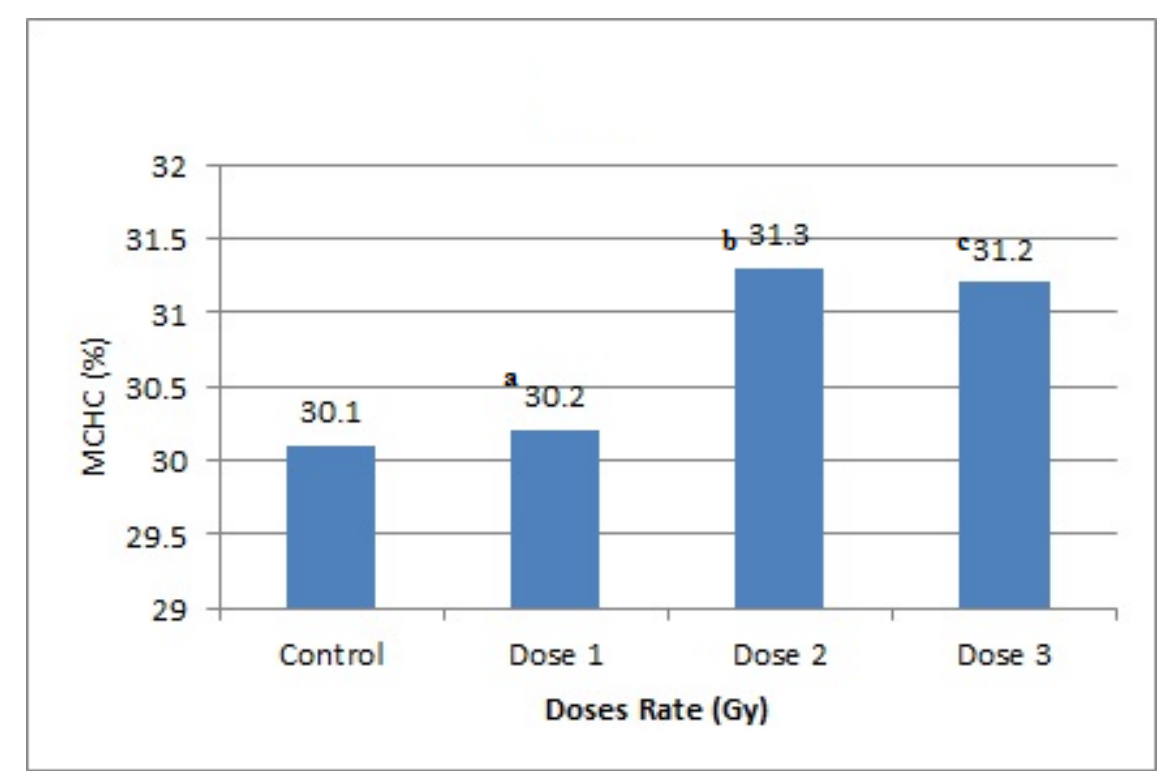

Figure 6 - Effect of low doses of gamma ray on $\mathrm{MCHC}(\%)$ counts in female rats. (a, b and c:means no change in significant) 


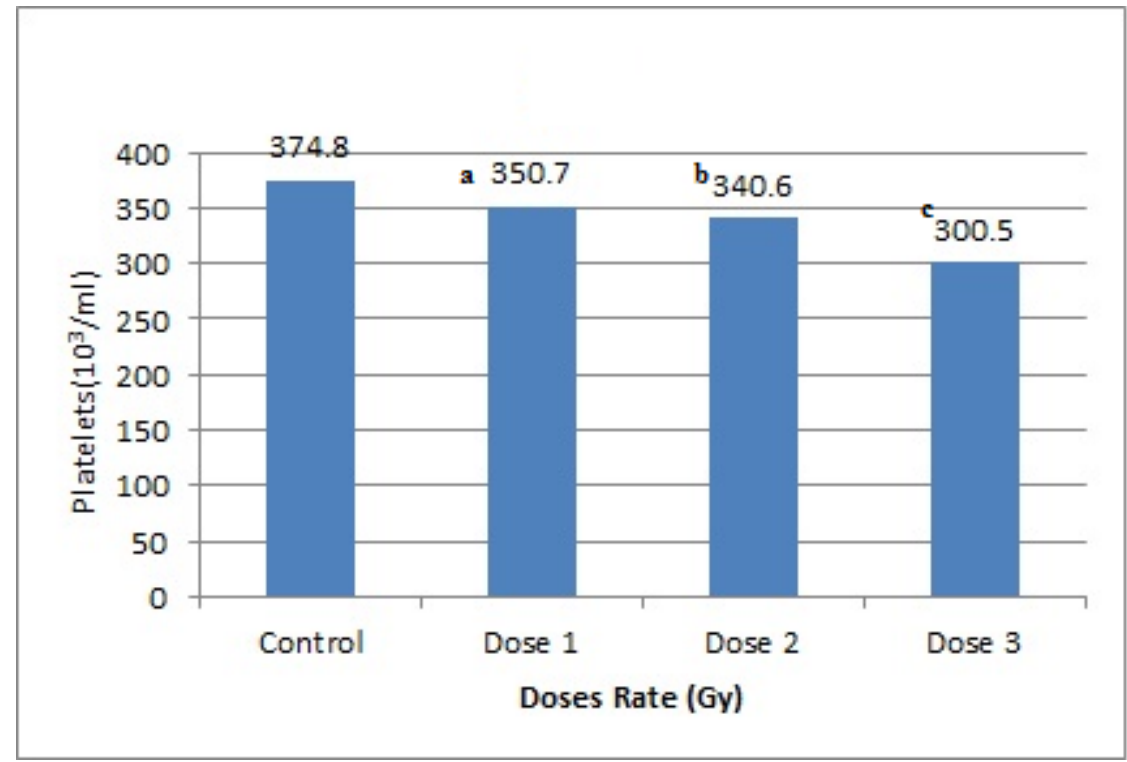

Figure 7 - Effect of low doses of gamma ray on Platelets counts in female rats . (a, b and c: means significant difference at $\mathbf{P}<0.05$ )

The formation of superoxide partially accounts for the well-known oxygen enhancement of radiation induced biochemical changes and cell damage. After whole body gamma irradiation at a low dose level a significant decline in $\mathrm{RBCs}, \mathrm{Hb}, \mathrm{Ht} \%$ and $\mathrm{WBCs}$ count was observed in rats [13].

Data presented in Figure (8) Showed that WBCs count was significantly decreased $(\mathrm{P} \leq 0.05)$ in rats treated with low $(0.165 \mathrm{~Gy})$ of gamma irradiation.
The higher dose $(0.165 \mathrm{~Gy})$ caused a significantly higher reduction in the lymphocytes count, monocytic count and neutrophils exhibited the same significant $(\mathrm{P} \leq 0.05)$ level observed with the WBCs count (see Figures (9-11)). In regard to the esinophiles and basophiles, they all decreased significantly at both irradiation exposure levels with a significant dose effect (Figures (12 and13)).

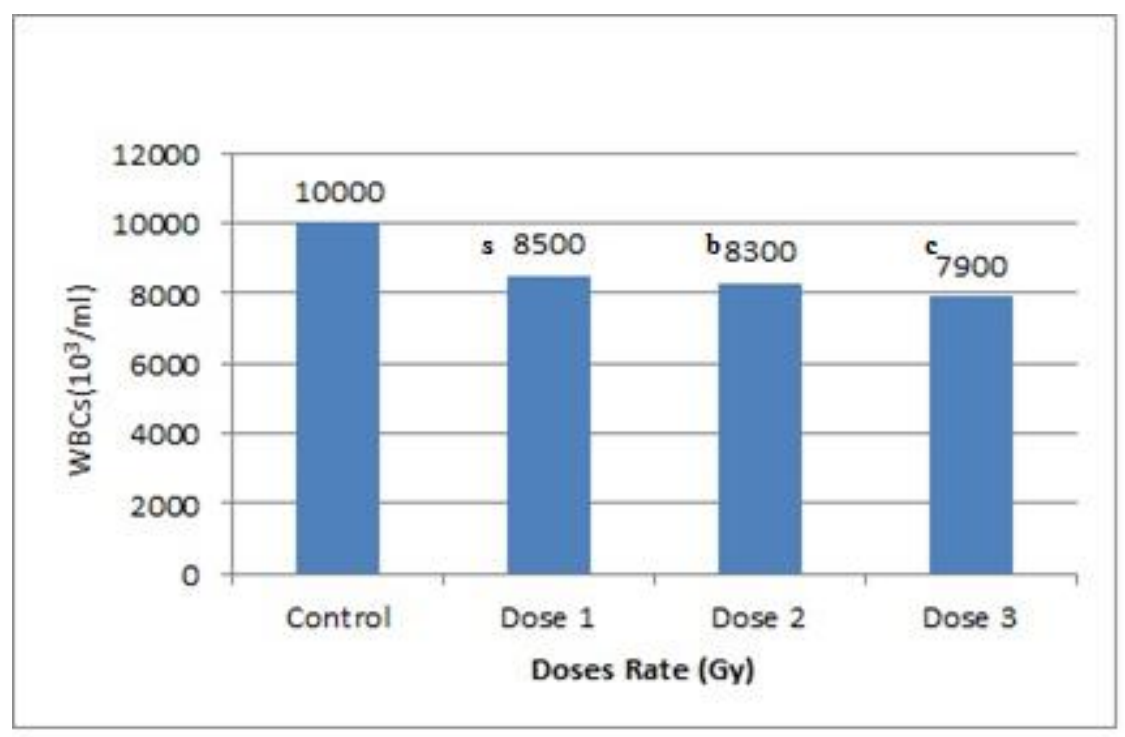

Figure 8 - Effect of low doses of gamma ray on WBCs counts in female rats (a, b and c:means significant difference at $\mathbf{P}<0.05$ ) 


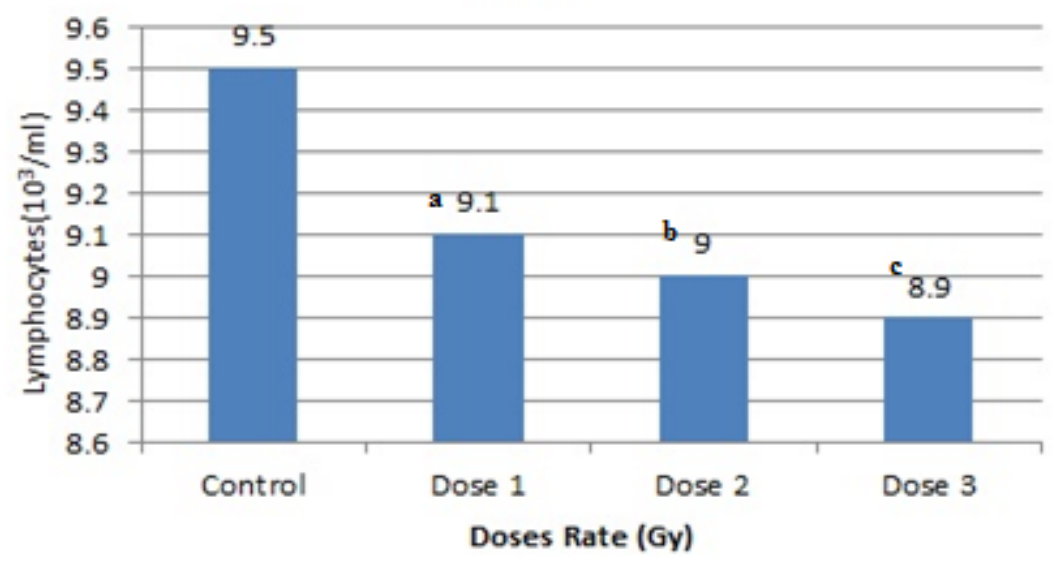

Figure 9 - Effect of low doses of gamma ray on Lymphocytes counts in female rats. (a, b and c: means significant difference at $\mathbf{P}<0.05$ )

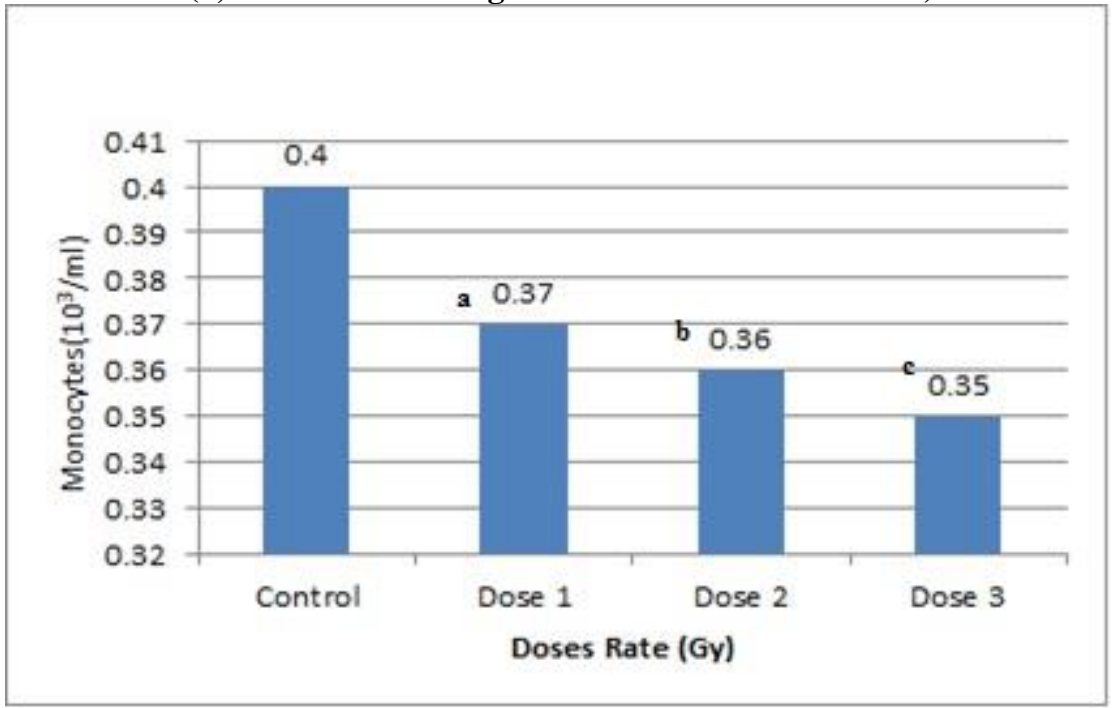

Figure 10 - Effect of low doses of gamma ray on Monocytic counts in female rats. (a, b and c: means significant difference at $\mathbf{P}<0.05$ )

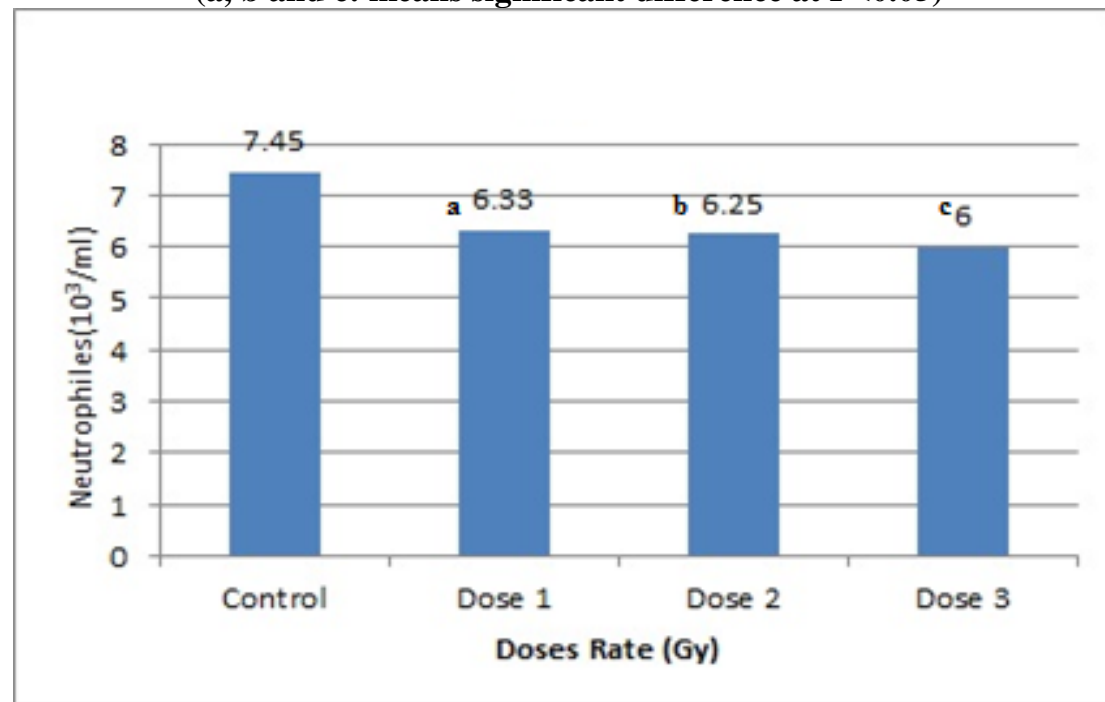

Figure 11 - Effect of low doses of gamma ray on Neutrophils counts in female rats. (a, b and c: means significant difference at $\mathrm{P}<0.05$ ) 


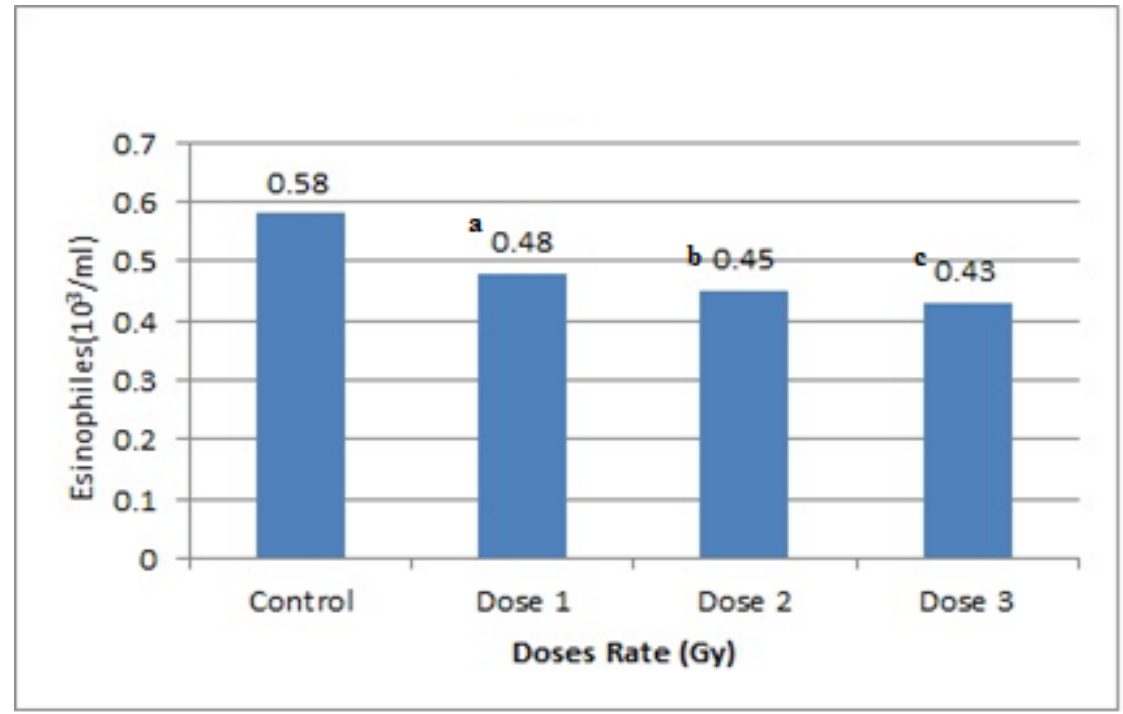

Figure 12 - Effect of low doses of gamma ray on Esinophiles counts in female rats. (a, b and c: means significant difference at $\mathbf{P}<0.05$ )

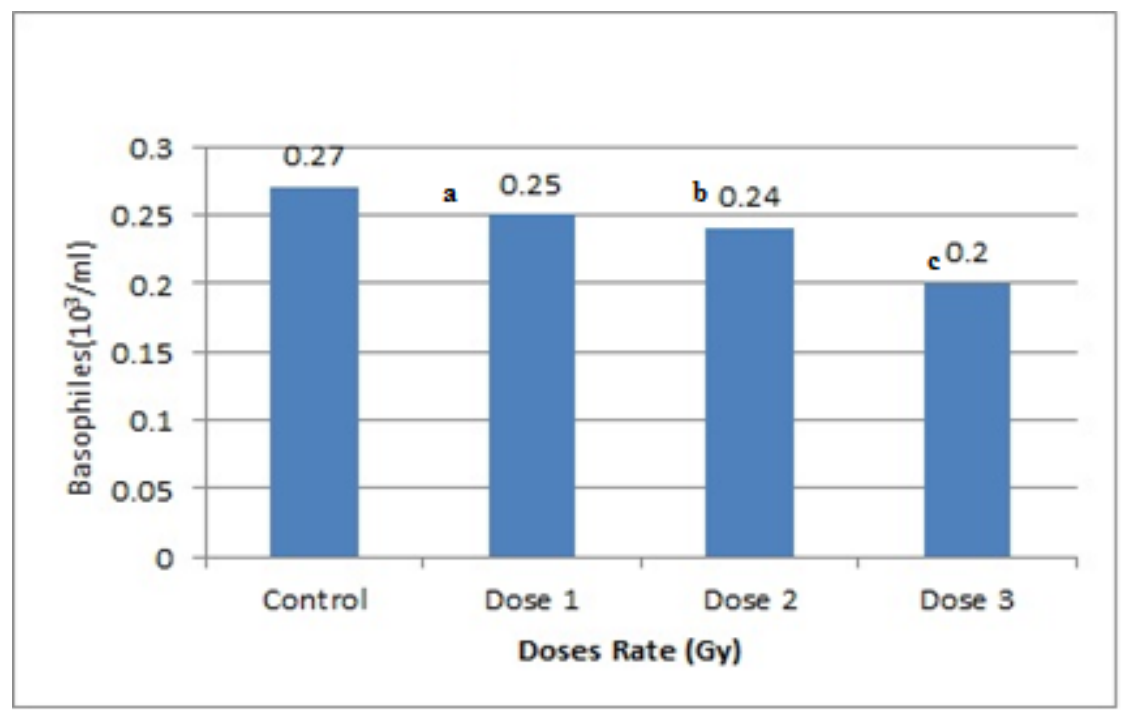

Figure 13 - Effect of low doses of gamma ray on Basophiles counts in female rats. (a, b and c: means significant difference at $P<0.05$ )

Gamma irradiation results in a decrease of the total count of WBCs, Lymphocytes, monocytes, neutrophils, basophils and esinophils [14]. The results are consistent with the previous findings that irradiation induced leucopenia [15] and reduces lymphocytes, neutrophils and monocytes count $[14$, 16]. The decreases could be attributed to high radio sensitivity of haematopoietic tissue [17] and a reduction in the viability of spleen hematopoietic stem cells [18].

\section{Conclusions}

In conclusion, this study has shown that the low doses of gamma ray could have dangerous on the some Hematological Parameters for blood of female rats. Exposures to ionizing radiation in the permissible range(ICRP-60) still have hazardous effects on RBCs and WBCs, therefore It is necessary to review the dose limits recommended by the ICRP60 for radiation workers based on the present findings.

\section{Acknowledgments}

A.A. would like to acknowledge all those who have contributed in this issue. Special thanks to the staff of the Department of Physics and Department of Biology at Kufa University. 


\section{References:}

1. (2005) U.S. Environmental Protection Agency, "Radiation Information: Fact Sheets Series on Ionizing Radiation", No. 2.

2. Soule BP, Hyodo F, Matsumoto KI, Simone NL, Cook JA, Krishna MC, et al. (2007) The chemistry and biology of nitroxide compounds. Free Radical Biology and Medicine, 42(11), 1632.

3. Camber H (1987) "Introduction to Health Physics", $2^{\text {nd }}$ edition. Pergamon Press. New York.

4. (2005) U.S. Environmental Protection Agency, "Understanding Radiation: Health Physics".

5. Gottllieb D, Shirling EB (1967) Cooperative description of type cultures of streptomycetes. I. The International of Streptomyces Project. Int. Syst. Bacteriol., 17: 315-76.

6. Ingram M, Roberts TAC (1980) Ionizing irradiation. In: Microbial Ecology of Foods, Vol. 1, pp. 46-69. ICMSF, Academic Press, New York.

7. Allehayanim SH, Sultan Monem (2003) Membrane solubilization and hemoglobin gelation as biomarker of radiation exposure to gamma-rays. Egyptian biophysics journal, vol.9, pp.234-244.

8. Omar Mohamed, Ihsan Hadajat, Ayman Ragab, Siham EL-Shinawy (2006) "Exposure of Rats to Whole Body Gamma Rays Induces Early Alterations in Biliary Secretion", Turk J Med Sci ; 36 (5 ): 263-269.

9. Asrar M. Hawas (2013) "Effect of low dose gamma rays on certain essential metals and xidative stress in different rat organs", journal of radiation research and applied sciences 6 , pp.38-44.

10. Jain NC (1986) Schalm's Veterinary Haematology, 4th ed. Lea and Fabiger, Philadelphia.
11. Dacie JV, Lewis SM (1991) Practical haematology, 7th edition, ELBS with Churchill Livingston, England, pp. 37-85.

12. Mitruka BM, Rawnsley H (1977) Clinical, biochemical and haematological references values in normal experimental animals. Masson Publishing USA Inc., pp. 53-54.

13. Abou-Seif MA, El-Naggar MM, El-Far M, Ramadan M, Saleh N (2003) Prevention of biochemical changes in gamma-irradiated rats by some metal complexes. Clin. Chem. Lab. Med., 41(7): 926-933.

14. Ezz MK (2011) The ameliorative effect of Echinacea purpurea against gamma radiation induced oxidative stress and immune responses in male rats. Aust. J. Basic \& Appl. Sci., 5(10): 506-512.

15. Mishima S, Saito K, Maruyama H, Inoue M, Yamashita T, Gu Y (2004) Antioxidant and immuno-enhancing effects of Echinacea purpurea Biol. Pharm. Bull., 27: 1004-1009.

16. Hari K, Sabu M, Lima P, Kuttan R (2004) Modulation of haematopoetic system and antioxidant enzymes by Emblica officinalis gaertn and its protective role against gammaradiation induced damages in mice J. Radiat. Res., 45: 549-555.

17. Chew B, Park J (2004) Carotenoid action on the immune response. J. Nutr., 134(1): 257S-261S.

18. Miura N, Satoh M, Imura N, Naganuma A (1998) Protective effect of bismuth nitrate against injury to the bone marrow by gammairradiation in mice: Possible involvement of induction of metallothionein synthesis. The Journal of Pharmacology and Experimental Therapeutics, 286: 1427-1430. 